\title{
Kinetic Reduction of Pellets of Mill Scale Waste and El-Dekheila Pellets Fine Waste using Coke Breeze
}

\author{
E. M. Abdel Hamid, M. E. H. Shalabi
}

\begin{abstract}
Mill scale is a valuable waste material that contains high amount of iron, little impurities and also is chemically stable composition. It is produced from the hot rolling processing in steel industry. The second waste is El-Dekheila pellets fine waste that produced as the results of handling in the El-Dekheila plant, West of Alexandria on the Northern coast of Egypt. This paper studies the recycling of mill scale and El-Dekheila pellets fine waste in iron and steel industries by reduction using coke breeze in the form of pellets. Characterization of raw materials were performed which are XRF, XRD and screen analysis. Reduction of pellets consisting of El-Dekheila pellets fine waste and different percentage of mill scale was investigated with 4 stoichiometric coke breezes using thermo-balance. The reduction increases with increasing coke breeze. The kinetics of reduction of these pellets were studied using different percentage of mill scale (20,60 and $80 \%$ ) and at different temperatures ranging from 900 to $1050^{\circ} \mathrm{C}$. The results displayed that the reduction process was controlled by Avrami and Erofeev involving nucleation of reduced phases followed by grain growth. Also, that the maximum reduction $80 \%$ can be reached after 125 minutes using $20 \%$ mill scale. The activation energies of reduced 20, 60 and $80 \%$ mill scale were found to be $112 \mathrm{~kJ}^{\mathrm{mol}}{ }^{-1}, 81 \mathrm{~kJ}^{\mathrm{mol}}{ }^{-1}$ and $107.8 \mathrm{~kJ}^{\mathrm{mol}}{ }^{-1}$ respectively.
\end{abstract}

Keywords: Kinetics, Reduction, Mill Scale, El-Dekheila pellets, Coke Breeze, Activation Energy

\section{INTRODUCTION}

Iron and steel industries produce a large amount of a solid waste during processing which are very valuable products and can be recycled and reused.

According to World Steel Association (WSA), they apply the philosophy of reuse, recycling and reduction [3R] to improve its sustainability. During 1970s to 1980s, $1440 \mathrm{~kg}$ of raw materials were needed to produce around $1000 \mathrm{~kg}$ of steel. Due to the technology improvements and researches, today steel industry uses about $1150 \mathrm{~kg}$ of raw materials to produce $1000 \mathrm{~kg}$ of steel which constitutes a reduction in the use of raw materials by about 20\%. During the last decade, slag,

Revised Manuscript Received on February 25, 2020.

* Correspondence Author

E. M. Abdel Hamid*, Chemical Engineering Department, Egyptian Academy for Engineering \& Advanced Technology (EAE\&AT), affiliated to Minstry of Military Production, Cairo, Egypt. Email: eman.mohamed@eaeat.edu.eg. PO box 3056, Cairo, Egypt

M. E. H. Shalabi, Central Metallurgical Research and Development Institute (CMRDI), El-Tabbin, Helwan, Cairo, Egypt. Email: mehshalabi@hotmail.com.

(C) The Authors. Published by Blue Eyes Intelligence Engineering and Sciences Publication (BEIESP). This is an open access article under the CC BY-NC-ND license (http://creativecommons.org/licenses/by-nc-nd/4.0/) sludge and dust produced from steel industry were called solid wastes but nowadays they are rather viewed as byproducts of these materials.

According to WSA, those by products can be recycled or recovered to the iron and steel industries or sold to be used in other industries. Slags, dusts, scrap and sludge are mainly produced from iron and steel industry. The major concern is the disposal of these solid wastes produced from steel industry process. So, reduce, reuse, and recycle are the three alternatives which need to be implemented by the iron and steel industry [1].

Mill scale is a valuable waste material that contains high amount of iron, little impurities and also is chemically stable composition. It is produced from the hot rolling processing in steel industry. It can be recycled back to the sintering plant [2].

Around $90 \%$ of mill scale waste is recycled in iron and steel industry while small amount can be used in cement plants and petrochemicals industry.

Mill scale can be recycled in a steel plant to produce iron ore pellets, iron ore sinter, briquettes after mixing with a binder which used in the reduction process in iron making furnace. Also mill scale can be used in different applications like batteries, catalysts and mixed fertilizers [3,4]. Studies related to the reduction of iron ore using coke breeze have been discussed. El-hussiny et al. [5] discussed the effect of partial replacement of Baharia iron ore with mill scale on different parameters of the sintering process and also discussed the effect of adding different amount of coke breeze on 95\% iron ore and 5\% mill scale. They found that increasing the amount of coke breeze used increasing the production of the sintering machine at blast furnace yard and also decreasing the reduction rate of sintering at $800{ }^{\circ} \mathrm{C}$. Oh et al. [6] also studied the reduction of hematite particles using carbon dioxide and hydrogen in isothermal thermogravimetric analysis at temperatures ranging from $550^{\circ} \mathrm{C}$ to $1300^{\circ} \mathrm{C}$. They found that the reduction rate increased as a result of increasing mole fraction of the reducing agent and surrounding temperature. The activation energy of iron oxide was found to be 43.5 $\mathrm{kJ}^{\mathrm{mol}}{ }^{-1}$ for hydrogen reduction while $2.3 \mathrm{~kJ}^{\mathrm{mol}}{ }^{-1}$ for carbon monoxide reduction. Also, Liu et al. [7] investigated the kinetics of reduction of wüstite using hydrogen or carbon monoxide. They not only found that the reaction passes through 3 steps including removal lattice oxygen in wüstite which the rate increased during conversion of solids but also that the rate of reaction using carbon monoxide was slower than hydrogen. On the other hand, Abd El Gawad et al. [8] investigated the reduction of briquettes of ilmenite ore fine using coke breeze at different temperatures.

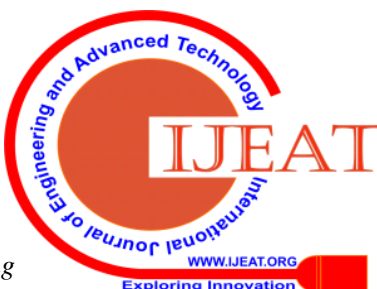


The results showed that the most suitable kinetic model for this reaction was found to be a diffusion-controlled model (Jander equation). Sarkar et al. [9] also investigated the reduction of briquettes of titaniferous magnetite ore (TMO) fines using coke dust at temperature ranging from $1000^{\circ} \mathrm{C}$ to $1200^{\circ} \mathrm{C}$ with varying the reduction time ranging from 5 to 60 minutes. They found that the maximum degree of metallization was $89.56 \%$ and the reaction activation energy was $59.52 \mathrm{~kJ} \cdot \mathrm{mol}^{-1}$.

Jeongseog and Dongsoon [10] studied the reduction of hematite particles in presence of $\mathrm{CO}$ and $\mathrm{H}_{2}$ atmosphere using thermo-gravimetric analysis (TGA). They found that the reduction rate of iron oxide particles increases with increasing reductant mole fraction and also found that the activation energy of hematite was $2.3 \mathrm{~kJ} \mathrm{~mol}^{-1}$ for $\mathrm{CO}$ and $43.5 \mathrm{~kJ} \mathrm{~mol}^{-1}$ for $\mathrm{H}_{2}$ at temperature ranging from $800{ }^{\circ} \mathrm{C}$ to $1300^{\circ} \mathrm{C}$. Nyankson and Kolbeinsen [11] also investigated the reduction of iron ore pellets using mixture of $\mathrm{H}_{2}-\mathrm{CO}$. They found that the reduction process is controlled by a combination of interfacial chemical reaction and solid-state diffusion.

On the other hand, Man et al. [12] discussed the kinetics reduction of iron ore-coal composite pellets. They found that the reduction process is controlled initially by diffusion at temperature below $900^{\circ} \mathrm{C}$ while above this temperature reached to $1100^{\circ} \mathrm{C}$ the mechanism of the reduction rate changed to phase-boundary controlled. While Yongsheng et al. [13] discussed the isothermally reduction of an Oolitic iron ore using coal at temperature ranging from $1150^{\circ} \mathrm{C}$ to $1300^{\circ} \mathrm{C}$. The results showed that the $\mathrm{C} / \mathrm{O}$ molar ratio and reduction temperature had a great effect on the reduction rate and the reduction rate is controlled by a combination of both interfacial chemical reaction and solid-state diffusion.

Similar studies showed that the reduction of hematite ore fines using a mixture of hydrogen and nitrogen by Zheng et al. [14] in a rotary drum at different temperature ranging from $700^{\circ} \mathrm{C}$ to $900^{\circ} \mathrm{C}$. The results showed that at temperature below $850^{\circ} \mathrm{C}$ the reduction was controlled by a 1 st order reaction model, while at temperature $900^{\circ} \mathrm{C}$ the reaction followed the previous was diffusion-controlled reaction model at the final stage of reduction process. It was found

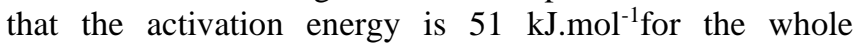
reduction process.

Finally, Ze-hong et al. [15] studied the kinetics reduction of hematite using coke for non-isothermal and isothermal thermodynamic analyses. They found that the behavior of both isothermal and non-isothermal reduction process was controlled by Avrami-Erofeev model and the activation energy was $171.25 \mathrm{~kJ} \mathrm{~mol}^{-1}$ for isothermal reduction process. In the present work, reduction of mixture of El-Dekheila waste pellets and mill scale using coke breeze was studied at different percentage of mill scale addition in the form of pellets. The reaction kinetics were also studied at different temperatures ranging from $900^{\circ} \mathrm{C}$ to $1050^{\circ} \mathrm{C}$.

\section{MATERIAL AND METHODS}

\section{A. Characterization of Raw Materials}

El-Dekheila pellets fine waste was collected from El-Dekheila steel Company (El-Dekheila, Alexandria) while rolling mill scale was kindly provided by the Egyptian Iron and Steel Company (Helwan, Cairo). The chemical composition of coke breeze, mill scale and El-Dekheila waste was determined using $\mathrm{X}$-ray fluorescence spectrometry and

is shown in "Table. I".

X-ray analyses of El-Dekheila pellets waste, mill scale and carbon breeze are shown in "Fig. 1". Hematite is the main phase present in El-Dekhaila pellets fine waste, mill scale consists of a mixture of iron oxides (wüstite, magnetite, and hematite) besides quartz. On the other hand, coke is mainly composed of graphite and quartz. Its XRD pattern displays poor crystallinity.

Table I: Chemical Analysis of Raw Materials

\begin{tabular}{|c|c|c|c|}
\hline $\begin{array}{c}\text { Constituent, } \\
\text { wt.(\%) }\end{array}$ & $\begin{array}{c}\text { Mill } \\
\text { Scale }\end{array}$ & $\begin{array}{c}\text { El-Dekheila Pellets } \\
\text { Fine Waste }\end{array}$ & $\begin{array}{c}\text { Coke } \\
\text { Breeze }\end{array}$ \\
\hline $\mathrm{Fe}_{\text {tot }}$ & 69.33 & 66.5 & - \\
\hline $\mathrm{Fe}_{\text {metal }}$ & 1.74 & - & 1.16 \\
\hline $\mathrm{Fe}_{2} \mathrm{O}_{3}$ & 70 & 95 & 8.24 \\
\hline $\mathrm{Fe}_{3} \mathrm{O}_{4}$ & 17.26 & - & 0.75 \\
\hline $\mathrm{FeO}$ & 7.83 & - & - \\
\hline $\mathrm{S}$ & 0.33 & - & - \\
\hline $\mathrm{P}$ & 0.22 & - & - \\
\hline $\mathrm{MnO}$ & 0.66 & - & - \\
\hline $\mathrm{SiO} 2$ & 1.92 & 1.5 & - \\
\hline $\mathrm{C}$ & 0.04 & - & 90.6 \\
\hline $\mathrm{CaO}$ & - & 0.7 & - \\
\hline Volatile & & - & 1.16 \\
\hline $\mathrm{Matter}$ & - & - & 8.24 \\
\hline Ash & - & - & 0.75 \\
\hline Humidity & - & & \\
\hline & & & \\
\hline
\end{tabular}
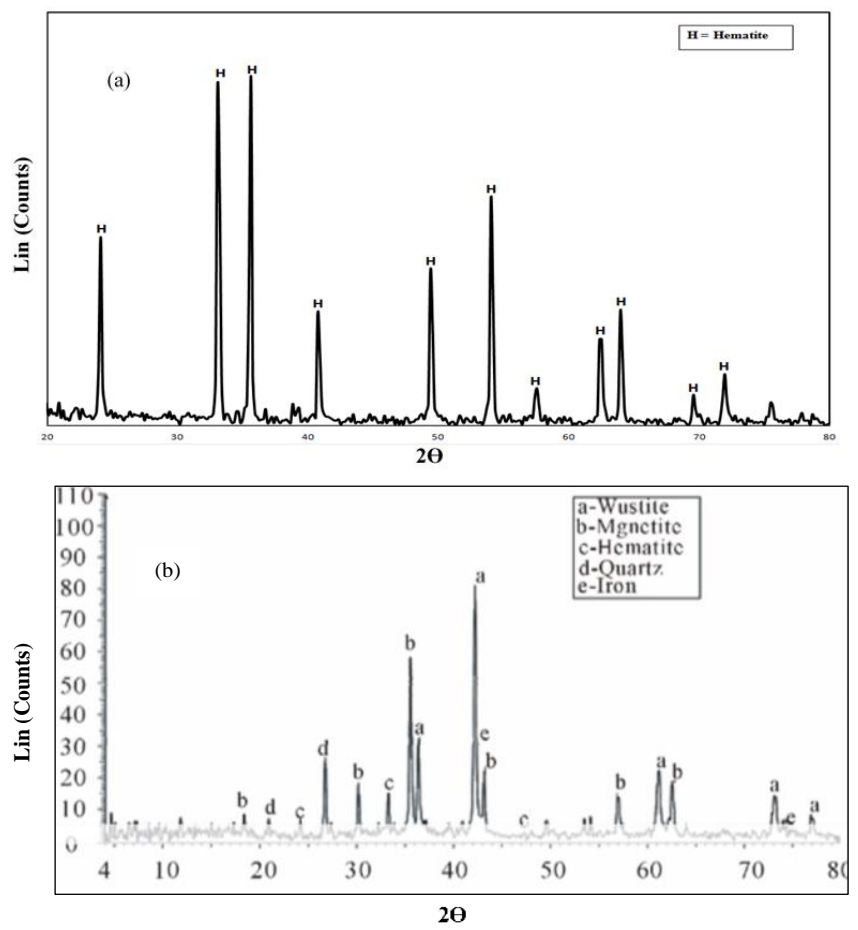


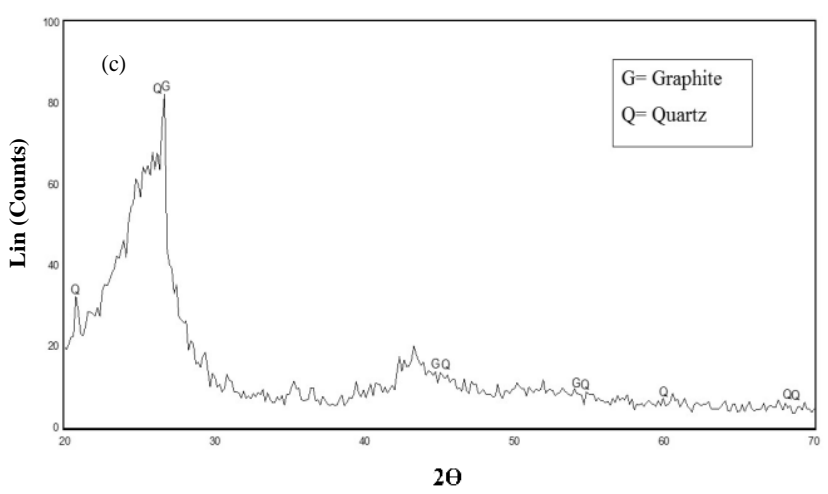

Fig. 1. XRD pattern of raw materials: (a) El-Dekheila waste pellets fines, (b) Mill scale, (c) Coke Breeze

Sieve analysis of the raw materials used in this study revealed that coke breeze was much finer than fine pellets and mill scale as evidenced from "Fig. 2". The median particle sizes $\left(\mathrm{D}_{50}\right)$ were $0.07 \mathrm{~mm}, 0.055 \mathrm{~mm}$ and 0.19 for coke breeze, pellet fine waste and mill scale respectively.

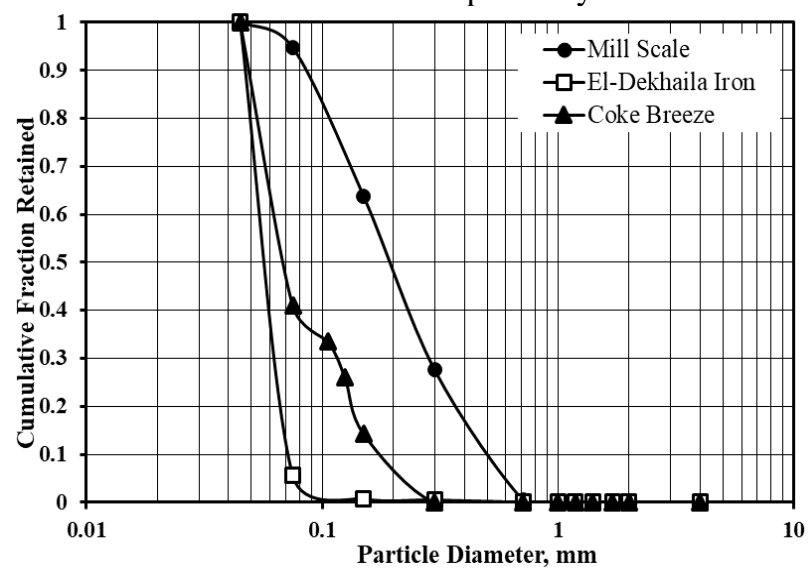

Fig. 2. Sieve Analysis of Raw Materials

\section{B. Experimental Methods}

To target the maximum reduction, Mill scale (M) and coke breeze were mixed together with different stoichiometric ratios of coke breeze $(1,1.25,1.5,1.75,2,3,4)$. The following procedure takes place to produce pellets of El-Dekheila pellets waste and Mill scale:

1. Mill scale (M) and El-Dekheila pellets fine waste (E) were mixed together with different percentages varying from $0 \%$ to $100 \%$ of mill scale in presence 4 stoichiometric coke breeze with $2.5 \%$ wt. molasses and $8 \%$ wt. water as binders.

2. Pelletization of El-Dekheila pellets fine waste (E) with Mill scale (M) in presence of coke were done in a disc pelletizer shown in "Fig. 3" with $400 \mathrm{~mm}$ diameter, $100 \mathrm{~mm}$ collar, $60^{\circ}$ angle of inclination with disc rotating speed $17 \mathrm{rpm}$ and 30 minutes as a residence time.

3. The raw materials were fed to the disc pelletizer then sprayed onto the rolling bed. The green pellets with size ranging from 5-8 $\mathrm{mm}$ diameter were screened out to dry then fed to the furnace.

4. Both drop number and crushing strength were determined after three days to ensure complete drying of samples.

5. The formed pellets were reduced using thermo-balance. Nitrogen was flown during reduction experiment as an inert gas with volume flowrate 0.5
L. $\min ^{-1}$.

6. The weight of sample was continuously recorded every 5 minutes and the weight loss was considered to be due to oxygen and carbon removal.

7. The extent of reduction $\alpha$ was determined using the following equation [5]:

$\alpha=\frac{\left(W_{0}-W\right) \times 16 \times 100}{\text { Mass of Oxygen } \mathrm{x} 28}$

Where:

$\mathrm{W}_{\mathrm{o}}=$ Initial mass of sample after removal of moisture (g).

$\mathrm{W}=$ Mass of sample after time $\mathrm{t}(\mathrm{g})$.

The mass of oxygen is the amount of oxygen present in the sample in the form of $\mathrm{FeO}, \mathrm{Fe}_{2} \mathrm{O}_{3}$, and $\mathrm{Fe}_{3} \mathrm{O}_{4}$.

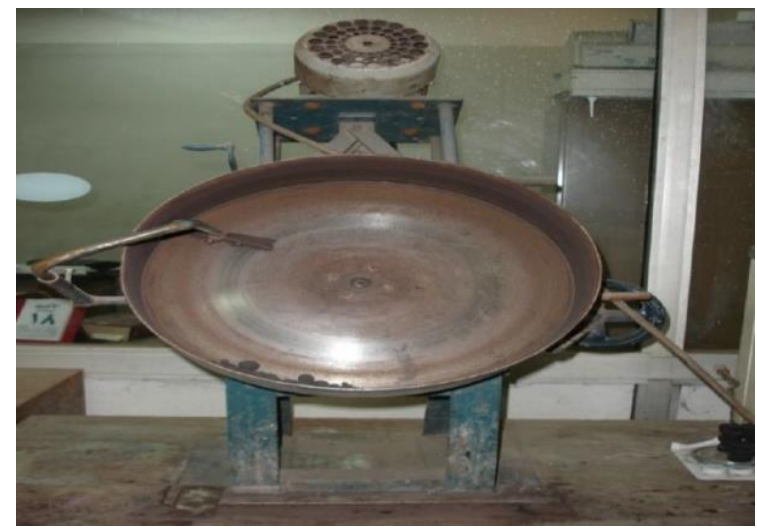

Fig. 3. Disc Pelletizer [16]

\section{RESULTS AND DISCUSSIONS}

\section{A. Effect of Coke Stoichiometry on Drop Number and Crushing Strength}

"Fig. 4a" illustrates the effect of coke stoichiometry on both drop number and crushing strength of green specimens of $100 \%$ mill scale. From figure it is showed that increasing amount of stoichiometric coke breeze increasing both drop damage resistance and crushing strength.

\section{B. Effect of Mill Scale Addition on Drop Number and Crushing Strength}

On adding mill scale to pellets fine waste in presence $4: 1$ stoichiometric coke, $2.5 \%$ binder.

It was observed in "Fig. 4b" that the drop number decreased from 6 to 4 as the percent mill scale was varied from 0 to $100 \%$ while green crushing strength decreased on adding mill scale to fine pellets waste, its values ranging from 0.017 to $0.0107 \mathrm{MPa}$.

\section{Effect of Coke Stoichiometry on Reduction at Temperature $1000^{\circ} \mathrm{C}$}

"Fig. 5a" shows the reduction of $100 \%$ mill scale pellets using coke breeze with different stoichiometry at temperature $1000^{\circ} \mathrm{C}$. The curve indicates that increasing coke stoichiometry enhancing the reduction percentage of pellets. "Fig. 5b" illustrates this result as the maximum reduction percent clearly increased with increased coke stoichiometry. 

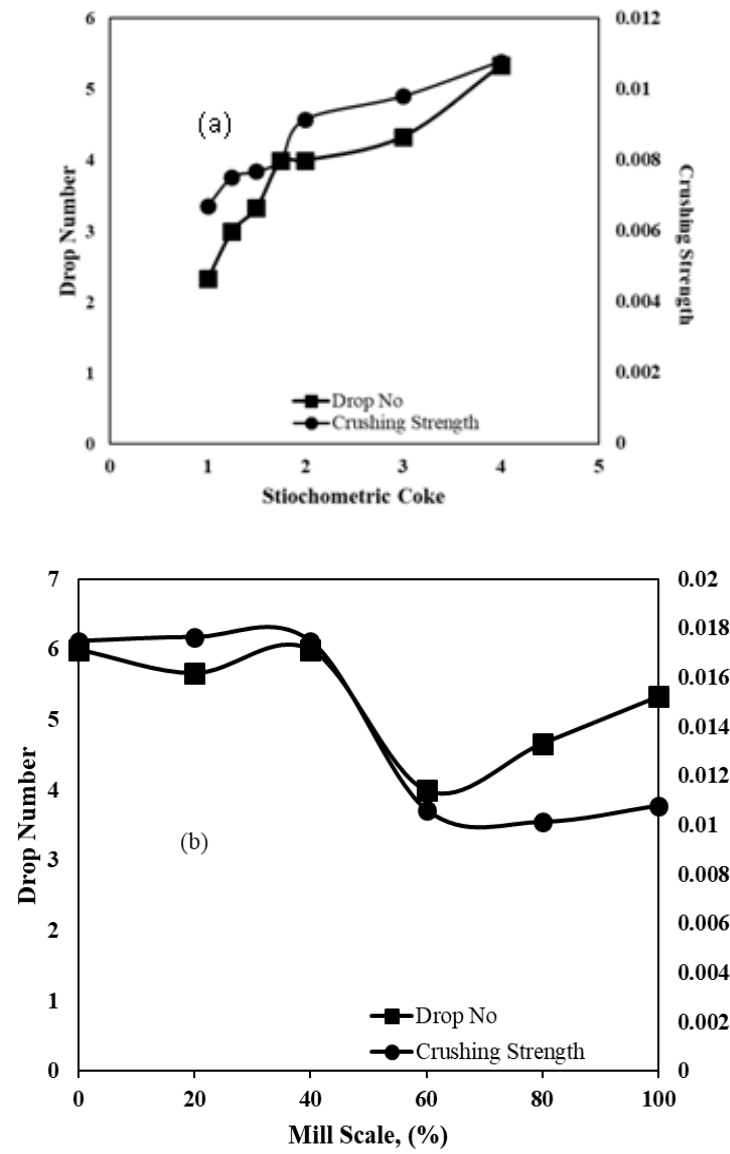

Fig. 4. Effect of (a) coke stoichiometry, (b) mill scale addition on drop number and crushing strength of dried samples
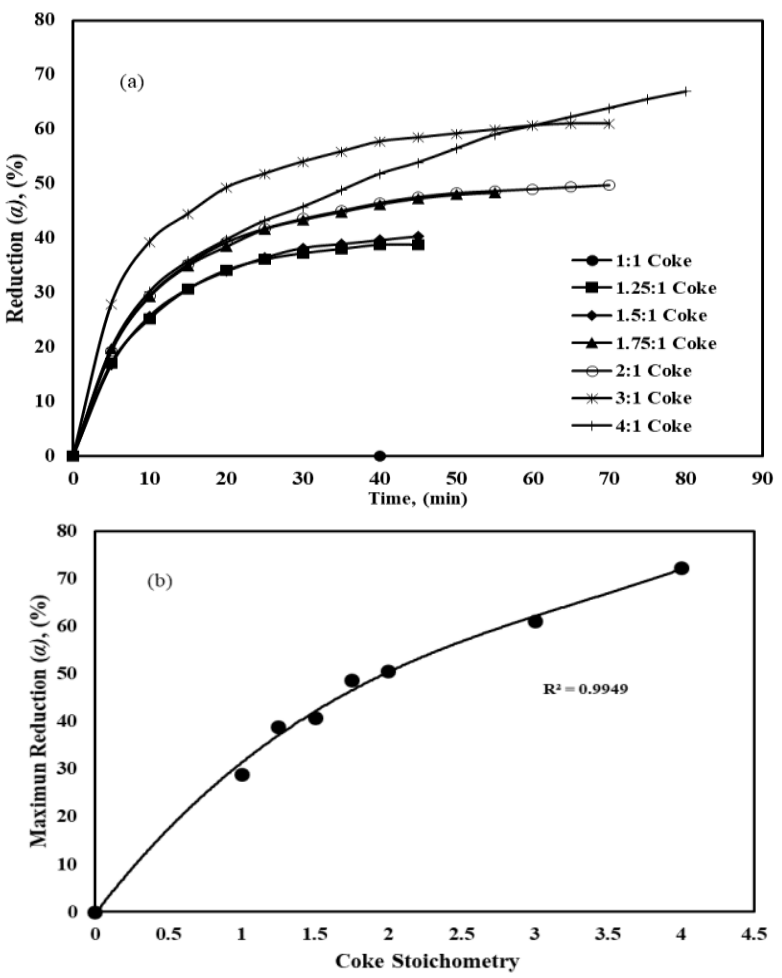

Fig. 5. Effect of coke stoichiometry on (a) reduction at temperature $1000^{\circ} \mathrm{C}$ (b) maximum reduction

It was seemed that increasing coke stichometry results better reduction of mill scale so 4:1 coke stoichiometry was selected in this work. XRD is performed for samples containing $3: 1$ and $4: 1$ coke stoichiometry to compare between the two different stoichiometries. The results are displayed in "Fig. 6" that the limited extent of reduction for 3:1 coke stoichiometry yield only iron and unreacted oxides of iron while 4:1 coke stoichiometry yield iron, unreacted oxides and carbon. The reason of presence of unreacted oxides and carbon will be discussed later in the effect of temperature in the extent of reduction.
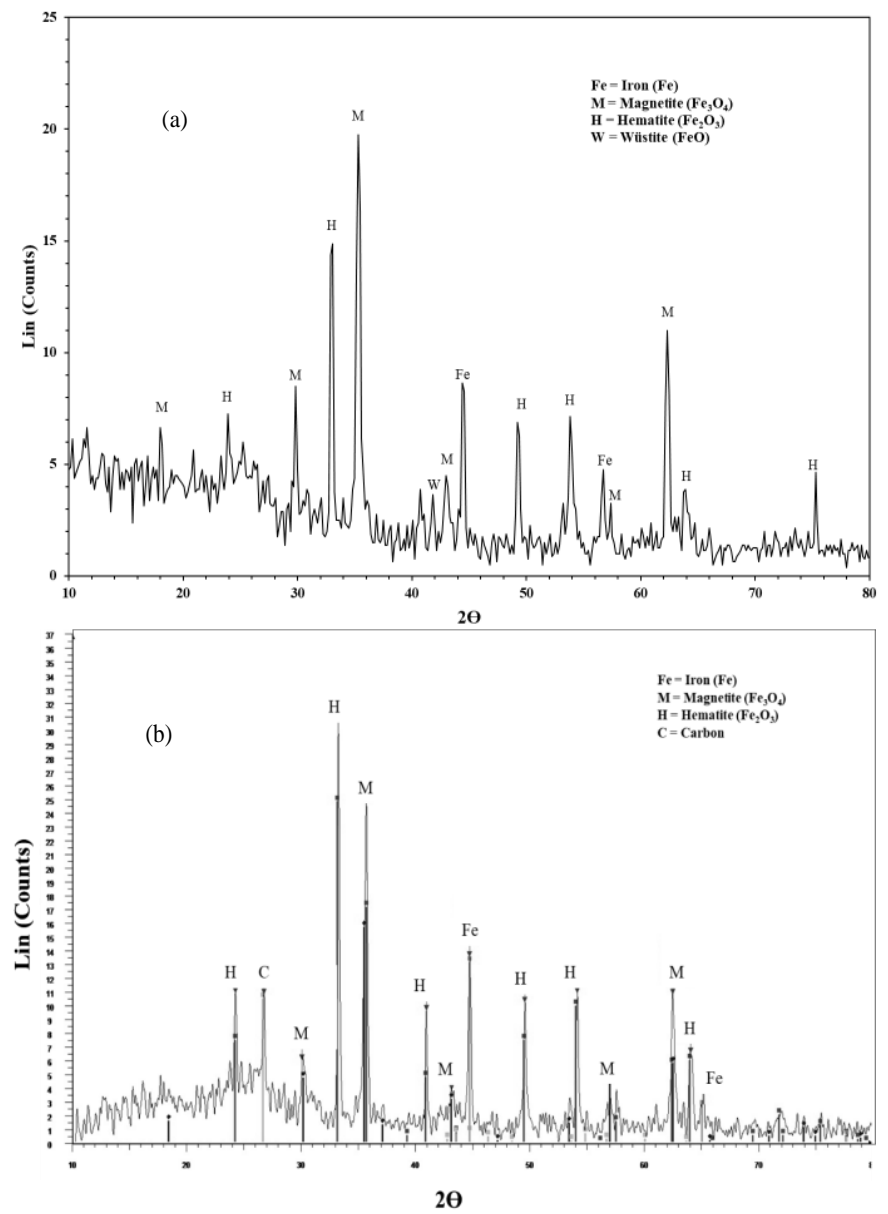

Fig. 6. XRD of pellets reduced at $1000^{\circ} \mathrm{C}$ using (a) 3:1 stoichiometric coke breeze, (b) 4:1 stoichiometric coke breeze

\section{Effect of Mill Scale Addition on the Kinetics of Reduction}

The effect of mill scale addition on the reduction percentage at $1000^{\circ} \mathrm{C}$ of pellets containing $4: 1$ stoichiometric coke breeze is shown in "Fig. 7a". It illustrates that increasing mill scale addition decreasing the reducibility of the original fine waste. "Fig. 7b" displayed the effect of mill scale addition on the maximum reduction percentage of pellets. These values drop from about $82 \%$ at $0 \%$ mill scale down to about $74 \%$ when $80 \%$ mill scale was used. It was noticed that the maximum reduction percentage on using $100 \%$ mill scale was about $72 \%$.

Several attempts were made to identify the kinetic mechanism of the reduction reaction at different percentages of mill scale. The following linearized equation of "Avrami-Erofeev" [17] was used in which $\alpha$ represents the fractional reduction.

Published By:

Blue Eyes Intelligence Engineering 
$\ln [-\ln (1-\alpha)]=\ln \mathrm{k}+\mathrm{n} \ln \mathrm{t}$

As can be followed in "Fig. 8a", straight lines were obtained in all cases, revealing the validity of the model used.

"Fig. 8b" reveals that the linear lots are almost parallel with values of slopes ranging from 0.0136 to 0.0243 . Each slope represents the value of $n$ in "equation (2)". Next, the reaction rate constants could be obtained by plotting $[-\ln (1-$ $\alpha)]^{1 / n}$ versus t. The slopes of these plots represent the reaction rate constants. "Fig. 8c" illustrated that increasing the mill scale content decreasing the slope of the straight lines obtained and hence the reaction rate constant for reduction.
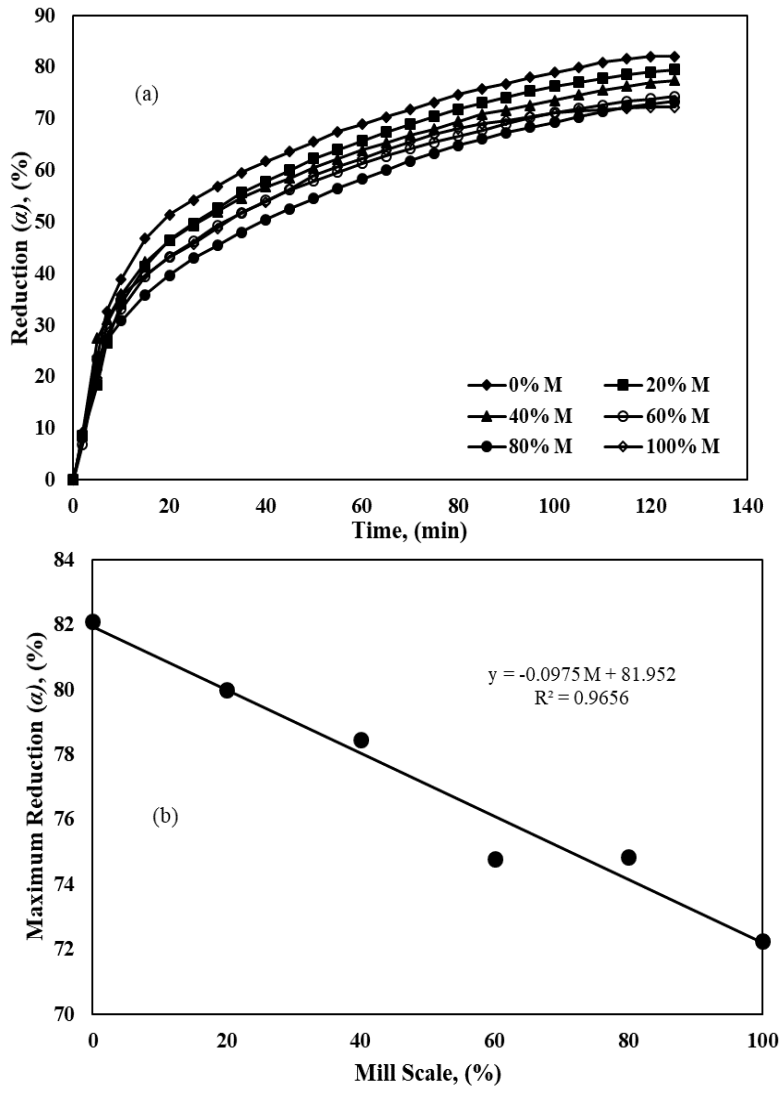

Fig. 7. Reduction Curves of Pellets Containing 4:1 Coke Breeze at ${ }^{1000^{\circ} \mathrm{C}}$ (a) Effect of mill scale addition on reduction (b) Effect of mill scale on maximum reduction

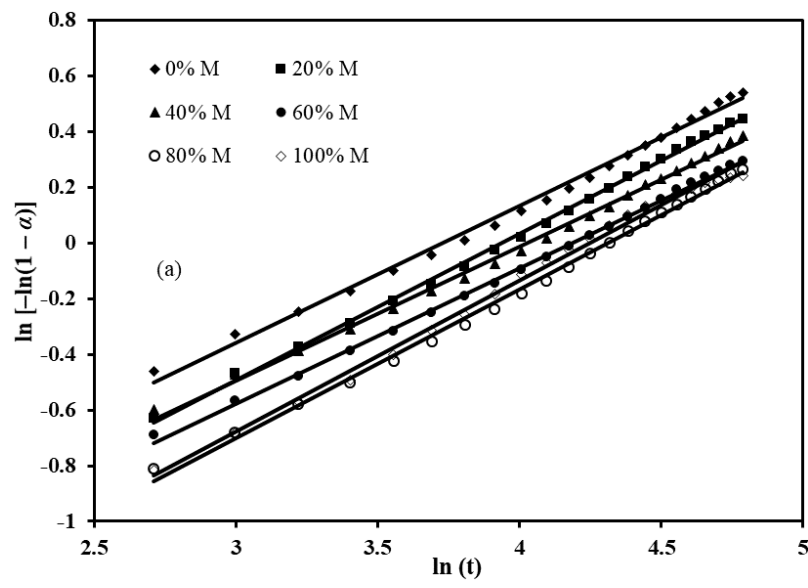

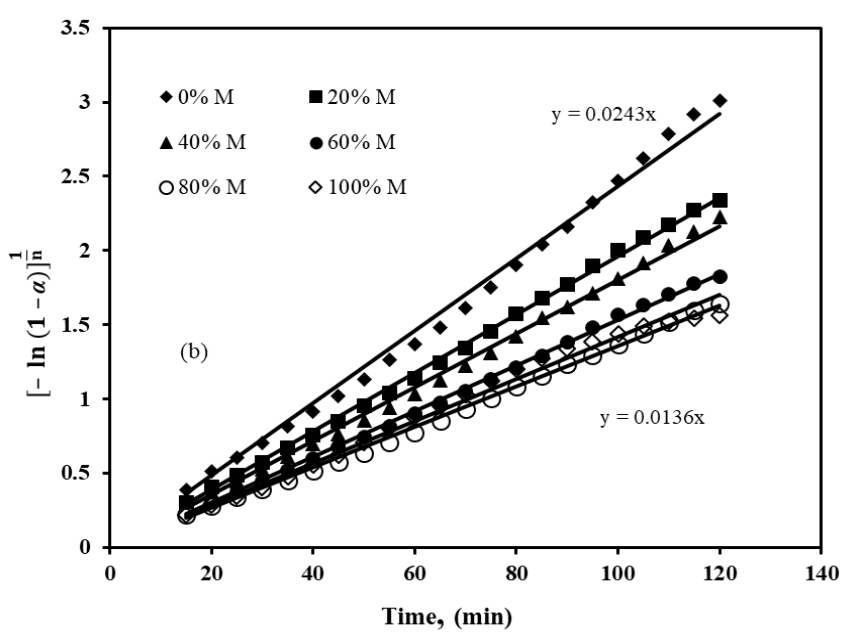

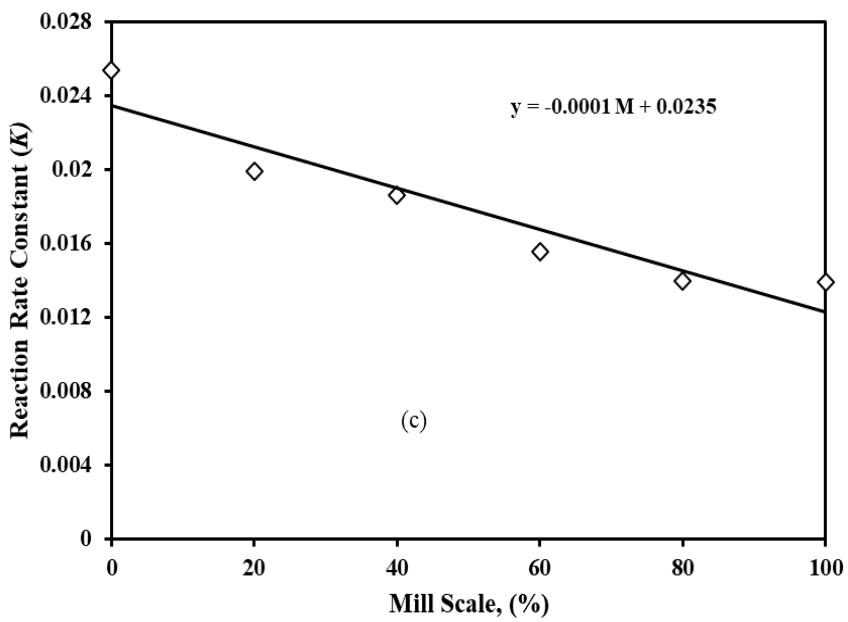

Fig. 8. Effect of mill scale addition at $1000^{\circ} \mathrm{C}$ on (a) Avrami - Erofeev Plot, (b) Linearized plots of (- In (1 $\alpha))^{1 / n}$ against time, (c) Reaction Rate Constants

\section{E. Kinetics of Reduction of Pellets Using Coke Breeze}

The effect of increasing the reduction at temperature ranging from $900{ }^{\circ} \mathrm{C}$ to $1050^{\circ} \mathrm{C}$ was responsible on the increasing the speed of the reaction. Because of the endothermic character of the reduction process, increasing the temperature resulted in higher percentages of reduction. Three different mill scale percentages were chosen to that aim, which are 20\%, 60\% and $80 \%$. In all three cases, the model that best fitted experimental data was Avrami - Erofeev [18] according to the following relation between conversion $(\alpha)$ and time $(\mathrm{t})$ : $\alpha=1-\exp \left(-k t^{\mathrm{n}}\right)$

To obtain as straight line:

$$
\ln (1-\alpha)=\mathrm{k} \cdot \mathrm{t}^{\mathrm{n}}
$$

$\ln [-\ln (1-\alpha)]=\ln \mathrm{k}+\mathrm{n} \ln \mathrm{t}$

A plot of $\ln (-\ln (1-\alpha))$ is first performed to obtain a straight line of slope (n).

"Equation (4)" can then be rewritten as follows:

$t=\left(\frac{1}{k}\right)^{\frac{1}{n}}[-\ln (1-\alpha)]^{\frac{1}{n}}=\frac{1}{K}[-\ln (1-\alpha)]^{\frac{1}{n}}$

Or:

$K . t=[-\ln (1-\alpha)]^{\frac{1}{n}}$

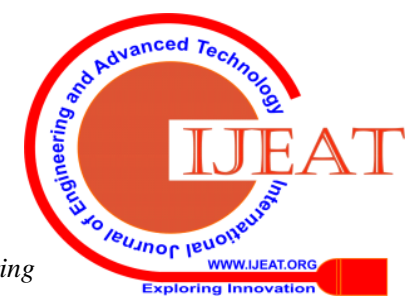


Hence, a plot of $[-\ln (1-\alpha)]^{1 / n}$ against t should yield a straight line of slope $=\mathrm{K}$, the reaction rate constant.

"Fig. 9" illustrated the results obtained from the reduction of $80 \%$ mill scale at different temperatures. The maximum reduction percentage reached to $78 \%$ after 120 minutes at $1050^{\circ} \mathrm{C}$.

Avrami - Erofeev plots are illustrated in "Fig. 10" where straight lines with varying slopes were obtained. These slopes decreased with increasing temperature as shown in "Table. II". Then values of $[-\ln (1-\alpha)]^{1 / n}$ were plotted versus $t$ to obtain reaction rate constants $\mathrm{k}$ at the four investigated temperatures. It was obvious from "Fig. 11" that the values of the slopes of the straight lines $(\mathrm{k})$ increased with temperature from $0.0066 \mathrm{~min}^{-1}$ at $900^{\circ} \mathrm{C}$ to about $0.0218 \mathrm{~min}^{-1}$ at $1050^{\circ} \mathrm{C}$. Arrhenius plots were illustrated finally in "Fig. 12" to show that straight lines were obtained on plotting (ln K) against $(1 / T)$ for the three level of mill scale addition. From the slope which equals to $\mathrm{E} / \mathrm{R}$, the results can be concluded in "Table. III". It seems therefore that the presence of mill scale causes the activation energy of reduction reaction to decrease till reach to a certain value then increase again.

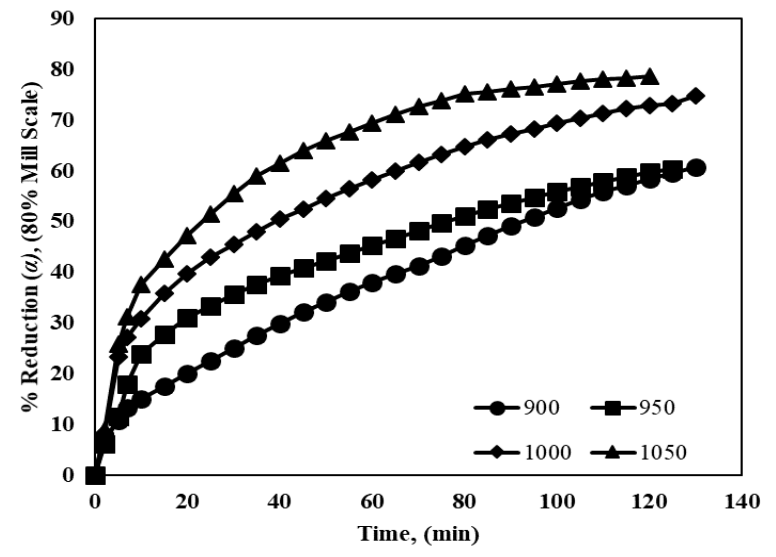

Fig. 9. Effect of Temperature on the Reduction of Pellets Containing $80 \%$ Mill Scale

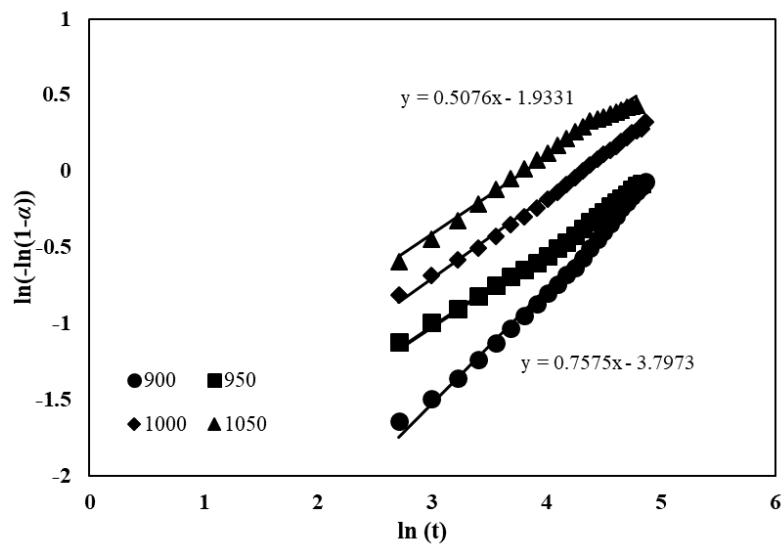

Fig. 10. Avrami - Erofeev Plot for Pellets Reduction Containing $80 \%$ Mill Scale

Table II: Avrami- Erofeev Slopes at Different Temperatures

\begin{tabular}{|c|c|}
\hline \multicolumn{2}{|c|}{ Temperatures } \\
\hline Temperature $\left({ }^{\circ} \mathrm{C}\right)$ & Slopes $[(\ln (-\ln (1-\alpha)) / \ln (t)]$ \\
\hline 900 & 0.75 \\
\hline 1050 & 0.5 \\
\hline
\end{tabular}

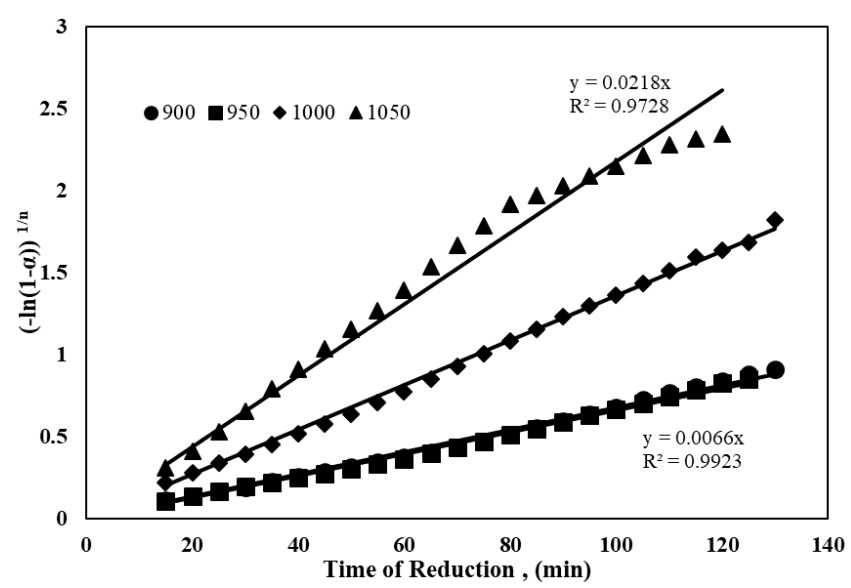

Fig. 11. Linearized Plots of $(-\operatorname{Ln}(1-\alpha))^{1 / n}$ against Time for the Reduction of Pellets Containing $80 \%$ Mill Scale

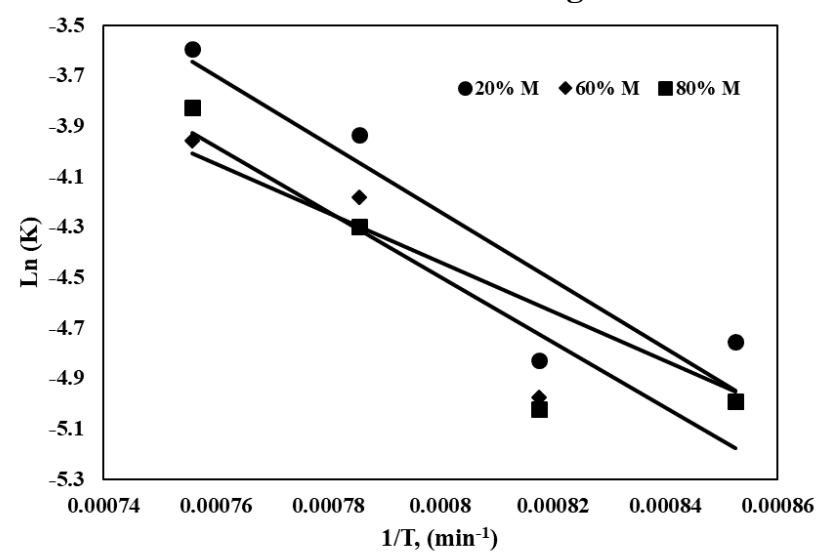

Fig. 12. Arrhenius Plots for Different Percentage of Mill Scale (M)

Table III: Activation Energies for Different Mill Scale Percentage

\begin{tabular}{|c|c|}
\hline Mill Scale Percent (wt.\%) & Activation Energy $\left(\mathrm{kJ} . \mathrm{mol}^{-1}\right)$ \\
\hline 20 & 112 \\
\hline 60 & 81 \\
\hline 80 & 107.8 \\
\hline
\end{tabular}

\section{CONCLUSION}

Mill scale is a valuable waste that contains high amount of iron while El-Dekheila iron pellets waste that produced as result of handling. The main aim of this study to investigate the possibility of recycling two different wastes in iron and steel industry that reduced using coke breeze.

El-Dekheila iron pellets waste was mixed with different percentage of mill scale ranging from 0 to $100 \%$ by increasing 20\%. Pelletization of mixture of mill scale and El-Dekhelia pellets fine waste were done in presence of $4: 1$ stoichiometric coke using $2.5 \mathrm{wt}$ \% of molasses and $8 \mathrm{wt} . \%$ of water as binders. The samples obtained were reduced in a thermo-balance in presence nitrogen with a flow rate 0.5 L.min ${ }^{-1}$ at different temperatures ranging from $900^{\circ} \mathrm{C}$ to $1050^{\circ} \mathrm{C}$. Kinetic reduction was studied and the following conclusions could be drawn: 
a) The best reduction can be reached using 4:1 stoichiometric coke.

b) The highest reduction level reached was $80 \%$ after 125 minutes using $20 \%$ mill scale.

c) The temperature has a great effect on the extent of the reaction which enhanced the reduction process.

d) The reduction process was found to be controlled by nucleation of the produced phases followed by grain growth (Avrami- Erofeev model).

e) Activation energies of reduction at 20,60 and $80 \%$ mill scale were found to be $112 \mathrm{~kJ} \cdot \mathrm{mol}^{-1}, 81 \mathrm{~kJ} \cdot \mathrm{mol}^{-1}$ and 107.8 $\mathrm{kJ} . \mathrm{mol}^{-1}$ respectively.

\section{REFERENCES}

1. Solid Waste Management in a Steel Plant, (April 2019), Retrieved from http://ispatguru.com/solid-waste-management-in-a-steel-plant/.

2. N. A. El-Hussiny, F. M. Mohamed and M.E.H. Shalabi, "Recycling of Mill Scale in Sintering Process", Sci. Sinter, 43, (2011), pp. 21-31.

3. N. M. Gaballah, A. F. Zikry, M. G. Khalifa, A. B. Farag, N. A. El-Hussiny and M. E. H. Shalabi, "Production of iron from mill scale industrial waste via hydrogen”, Open J. Inorg. Non- Met. Mater., 2013, 3, pp. 23-28.

4. Generation transport and uses of mill scale, (March 2019), Retrieved from

http://ispatguru.com/generation-transport-and-uses-of-mill-scale/.

5. N. M. Hashem, B. A. Salah, N. A. El-Hussiny, S. A. Sayed, M. G. Khalifa and M. E. H. Shalabi, "Kinetics reduction of El-Baharia iron ore (Egypt) via coke breeze", Int. J. Sci. Eng. Res., 6 (8), (2015), pp. 339-345.

6. J. Oh and D. Noh, "The reduction kinetics of hematite particles in $\mathrm{H}_{2}$ and CO atmospheres", Fuel, 196, (2017), pp. 144-135.

7. W. Liu, J. Y. Lim, M. A. Saucedo, A. N. Hayhurst, S. A. Scott and J. S. Dennis, "Kinetics of the reduction of wüstite by hydrogen and carbon monoxide for the chemical looping production of hydrogen", Chem. Eng. Sci., 120, (2014), pp. 149-166.

8. H. H. Abd El Gawad, N. A. El-Hussiny, M. A. Wassef, M. G. Khalifa, A. A. A. Soliman and M. E. H. Shalabi, "Reducibility Study of Rossetta Ilmenite Ore Briquettes and Powder with Coke Breeze at 800-1100C", Sci. Sint., 45, (2013), pp. 79-88.

9. B. K. Sarkar, M. G. Dastidar, R. Dey and G. C. Das, "A study on isothermal reduction kinetics of titaniferous magnetite ore using coke dust, an industrial waste", Can. Metall. Quart., (2018), pp. 1879-1395.

10. O. Jeongseog and N. Dongsoon, "The reduction kinetics of hematite particles in $\mathrm{H}_{2}$ and CO atmospheres", Fuel, 196, (2017), pp. 144-153.

11. Nyankson E., Kolbeinsen L., "Kinetics of direct iron ore reduction with CO-H2 gas Mixtures", Inter. J. Eng. and Tech. Res., 4 (4), (2015), pp. 934-940.

12. Y. Man, J. X. Feng, F. J. Li, Q. Ge, Y. M. Chen and J. Z. Zhou, "Influence of temperature and time on reduction behavior in iron ore-coal composite pellets", Powder Technol., 256, (2014), pp. 361-366.

13. S. Yongsheng, H. Yuexin, G. Peng, W. Xinchao and L. Guofeng, "Thermogravimetric study of coal-based reduction of oolitic iron ore: Kinetics and mechanisms”, Int. J. Miner. Process., 143, (2015), pp. 87-97.

14. W. Zheng, Z. Jing, Q. Baoping, D. Yue, L. Yang, L. Yuan, H. Wuxing and Z. Yongfa, "Reduction kinetics of hematite ore fines with $\mathrm{H} 2$ in a rotary drum reactor", Powder Technol., 332, (2018), pp. 18-26.

15. W. Ze-hong, L. Guo-feng, S. Yong-sheng and H. Ming-zhao, "Reduction behavior of hematite in the presence of coke", Int. J. of Mine. Metall. Mater., 23 (11), (2016), pp. 1244-1251.

16. N.M. Hashem, A. El-Amir, M. M. Ahmed, S. Th. Abdel-Rahim, M.E.H. Shalabi, "Kinetics of Direct Reduction El-Baharia (Egypt) iron ore pellets in static bed via Hydrogen", Int. J. Sci. Eng. Res., 6 (10), (2015), pp. 870-877.

17. A. Khawam and D. R. Flanagan, "Solid-state kinetic models: basics and mathematical fundamentals", J. Phys. Chem. B, 110 (35), (2008), pp. 17315-17328.

\section{AUTHORS PROFILE}

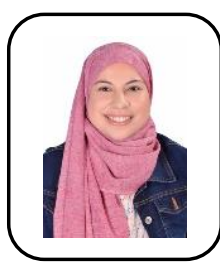

Eman received her B.Sc in Chemical Engineering, from Faculty of Engineering, Cairo University. She recived her M.Sc and worked as an assistant lecturer in Institute of Aviation Engineering \& Technology (IAET). She finished her Pre- Ph.D with GPA 3.9. She received her Ph.D and works as lecturer at Egyptian Academy for Engineering and Advanced Technology (EAE\&AT) since October 2018 till now. Eman published two papers and attend conferences. I have a good experience in different research fields such as kinetics of solid state, ceramics and bricks.

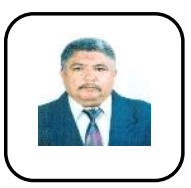

Mohamed El-Menshawi Hussein Shalabi received his B.Sc in Chemical Engineering in 1970 from Faculty of Engineering, Cairo University, he also received his M.Sc in 1973 and his Ph.D in 1980. He also received his Doctor of science in 1990. Mohamed works at Central Metallurgical Research and Development Institute (CMRDI) as a Professor of Chemical and Metallurgical Engineer in agglomeration department. He published more than 269 papers. His total citations since 2015 was found to be 499 according to google scholar.

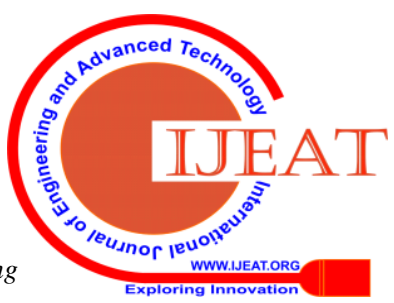

